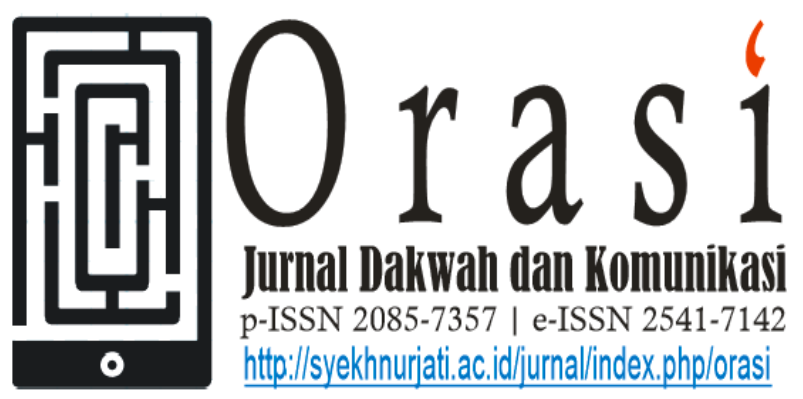

Volume 10 No. 2 Desember 2019

\title{
KONSTRUKSI REALITAS DAN FRAMING PEMBERITAAN RADARCIREBON.COM (Berita Penangkapan Teroris JAD di Tangkap Densus 88 di Kota Cirebon)
}

\section{CONSTRUCTION OF REALITY AND FRAMING OF NEWS RADARCIREBON.COM (News of JAD Terrorist Arrest by Densus 88 in Cirebon City)}

\author{
Fifi Novianty \\ Universitas Islam Negeri Sunan Kalijaga Yogyakarta \\ e-mail:@noviafifi.nf@gmail.com
}

\begin{abstract}
ABSTRAK
Penangkapan Teroris JAD di Kota Cirebon banyak menarik perhatian media massa lokal di Kota Cirebon, termasuk media online Radarcirebon.Com. Realitas yang disajikan oleh wartawan kedalam berita bukanlah realitas sebenarnya melainkan realitas yang telah di framing dan dikonstruksi media. Masalah yang dikaji peneliti adalah bagaimana Radarcirebon.com mengkonstruksi realitas penangkapan teroris JAD oleh Densus 88 serta framing apa yang dimunculkan dalam pemberitaannya. Penelitian ini menggunakan metode kualitatif, dan menggunakan analisis framing model Zhongdan Pan dan Pan and Kosicky. Dari hasil yang telah dianalisis peneliti, hasilnya menunjukan Radarcirebon.Com dalam memframing dan mengkonstruksi berita lebih menonjolkan pada judul berita dari data yang diperoleh dari Kepolisian dan menekankan pada kronologis kejadian panangkapan teroris JAD di Kota Cirebon. Struktur pemberitaan yang dikaji adalah elemen framing : skematik, skrip, tematik, dan retorika. Skematik: Radarcirebon.Com mengatakan seluruh terduga teroris berkaitan dengan kelompok Abu Zee JAD. Sumber berita utamanya adalah Kepolisian. Latar informasi yang disajikan penangkapan Teroris JAD oleh Densus 88. Skrip : Berita yang disajikan wartawan lebih menonjolkan kronologis kejadian penangkapan terduga teroris JAD secara beruntun. Tematik: Radarcirebon.com menyakini
\end{abstract}


seluruh terduga teroris punya keterkaitan dengan kelompok Abu Zee pimpinan JAD Bekasi dan perekrut Abu Rara pelaku penyerangan ke Pak Wiranto. Retoris: Radarcirebon.com memberikan penekanan pada teks berita dan elemen gambar.

Kata Kunci: Berita, Framing, konstruksi realitas

\begin{abstract}
JAD Terrorist Arrest in Cirebon City attracted a lot of local mass media in Cirebon City, including online media Radarcirebon.Com. The reality presented by journalists in the news is not actual reality but reality which has been framed and constructed by the media. The problem investigated by researchers is how Radarcirebon.Com constructed the reality of the capture of JAD terrorists by Detachment 88 and what framing was raised in its reporting. This study uses qualitative methods, and uses Zhongdan Pan and Pan and Kosicky's framing analysis models. From the results that have been analyzed by researchers, the results show Radarcirebon.Com in framing and constructing the news more prominently in the headline of the data obtained from the Police and emphasizes the chronology of JAD terrorist arrests in Cirebon City. The structure of the report studied is the framing element: schematic, script, thematic, and rhetoric. Schematic: Radarcirebon.Com says all suspected terrorists are related to Abu Zee $J A D$ group. The main news source is the Police. Background information presented by the capture of JAD Terrorists by Detachment 88. Scripts: News presented by journalists emphasizes the chronology of successive arrests of suspected JAD terrorists. Thematic: Radarcirebon.com believes all suspected terrorists have links to the Abu Zee group led by JAD Bekasi and Abu Rara recruiters who attacked the Pak Wiranto. Rhetorical: Radarcirebon.Com emphasizes news text and picture elements.
\end{abstract}

Keywords: Framing, news, reality construction

\section{Pendahuluan}

Konstruksi realitas media massa pada prinsipnya adalah menceritakan, mengkonseptualisasikan peristiwa, keadaan dan benda. Dalam media, konstruksi realitas lazim di sinonimkan dengan istilah framing atau pembingkaian. Framing menjadi bagian penting dalam praktik pemberitaan media massa. Dengan framing berita pada media massa akan lebih menarik pembaca, meskipun berita yang dibuat sudah dikonstruksi oleh media massa. Banyaknya berita yang di framing oleh media massa adalah berita yang mengandung polemik dan kontroversial, hal tersebut tentunya menjadi ajang benturan pemikiran atau ideologi pada kelompok tertentu.

Salah satu peristiwa sekarang ini yang sedang menjadi sorotan media massa adalah pemberitaan tentang terduga teroris JAD yang ditangkap oleh Densus 88, yang terjadi pada 18 October 2019 di Wilayah Hukum Polres Cirebon Kota. Aksi penangkapan teroris JAD oleh densus 88 tersebut membuat gembar masyarakat Kota dan Kabupaten Cirebon, karena berdasarkan pemberitaan Radar Cirebon telah tercatat sebanyak empat orang terduga teroris jaringan JAD yang ditangkap. 
Dan ada 3 wilayah di kota Cirebon yang menjadi Zona Merah yang di duga adalah tempat teroris yaitu Kecamatan Jamblang, Klangenan dan Plered.

Judul berita Radarcirebon.Com pada rentang waktu tanggal 14 October 2019 sampai 18 October 2019 dapat dipaparkan berikut ini: pada 14 October 2019 radar Cirebon.com menurunkan berita yang berjudul "Kronologi Penangkapan Terduga Teroris Cirebon", tanggal 18 October 2019 membuat berita berjudul "Di Wilayah Hukum Polres Ciko, Empat Terduga Teroris JAD di Tangkap Densus 88”, pada tangga 18 October 2019 pukul 08.00 WIB, memuat berita berjudul “Dua Rumah Terduga Teroris JAD di Geledah Densus 88 dan Polres Ciko". Pada hari yang sama, Radarcirebon.Com menurunkan berita berjudul "3 Kecamatan di Kabupaten Cirebon Masuk Zona Merah Paham Radikal" dan pada hari yang sama berita baru diturunkan kembali dengan judul "Densus 88 Tangkap Terduga Teroris di Pintu Keluar Asia Toserba”. 19 october penurunan berita yang berjudul " 40 Terduga Teroris Ditangkap Densus 88 Jelang Pelantikan Presiden".

Jadi topik tentang penangkapan Teroris JAD oleh Densus 88 menjadi perhatian media massa khususnya Radarcirebon.Com yang mana berita tersebut dapat dimuat lebih dari satu kali dalam sehari. Ini menunjukan perhatian yang besar dalam masalah ini sehingga kasus ini ditonjolkan (emphasize). Padahal, disaaat yang bersamaan ada peristiwa nasional maupun lokal lainnya di Kota Cirebon yang menyangkut kepentingan negara ini luput dari perhatian (de-emphasize). peristiwa yang dimaksud adalah 1) Persiapan Pelantikan Presiden, Persiapan Cikab Perketat Jalur Pantura dan 2) Penggeledahan Rumah Bupati Indramayu oleh KPK.

Dilihat dari realitas yang ada, media harus melakukan proses filtering, mana yang akan ditampilkan dan mana yang tidak. menurut pandangan konstruktivis, berita yang ada pada media massa adalah hasil konstruksi sosial dimana selalu melibatkan pandangan, ideologi, dan nilai-nilai dari wartawan dan media itu sendiri. Bagaimana realitas itu dijadikan berita sangat tergantung pada bagaimana fakta itu dipahami dan dimaknai. (Eriyanto, 2002: 26). Awak media dapat membatasi dan menafsirkan komentarkomentar sumber berita serta memberi porsi pemberitaan yang berbeda antara satu sumber dengan sumber lainnya. Serta mengemas suatu wacana berita perspektif, gaya bahasa, retorika dan common sense yang mereka kehendaki.

Berita yang muncul di media massa merupakan salah satu variasi dari penyampaian realitas kepada khalayak. Berita yang disajikan bukanlah realitas objektif tapi realitas subjektif yang kemudian hadir ke pembaca setelah melalui proses konstruksi. Jadi dengan kata lain, sebuah berita yang ada media massa dapat melalui proses kontruksi.

Latar belakang ini memunculkan pertanyaan, (Pertama) Bagaimana Radar Cirebon.Com mengframing berita teroris JAD ditangkap Densus 88 di Wilayah Hukum Polres Cirebon Kota dan (dua) apa frameframe yang ada dalam pemberitaannya. Dan adapun tujuan dari penelitian ini adalah untuk menemukan bagaimana Radar Cirebon.Com 
menframing berita teroris JAD ditangkap Densus 88 di Wilayah Hukum Polres Cirebon Kota.

\section{Landasan Teoritik}

\subsection{Analisis Framing}

Untuk menganalisis suatu berita secara garis besar dapat dilakukan dengan analisis teks (termasuk analisis framing). Dalam penelitian ini akan menggunakan analisis framning yang termasuk dalam paradigma konstruktivisme. Gagasan mengenai framing, pertamakali dilontarkan oleh Beterson (19551972) dalam Reese 2001, 37. Mulanya frame, dimaknai sebagai struktur konsepsual atau perangkat kepercayaan yang mengorganisir pandangan politik, kebijakan wacana serta yang menyediakan kategori-kategori standar untuk mengapresiasi realitas. Konsep ini lalu dikembangkan oleh Goffman (1974) yang mengandaikan frame sebagai kepinginankepinginan perilaku yang membimbing individu dalam membaca realitas (Fauzi, 2003: 22)

Wiliam A. Gamson mengatakan bahwa framing adalah cara bercerita atau gugusan ide-ide yang terorganisir sedemikian rupa dan menghadirkan konstruksi makna peristiwa-peristiwa yang berkaitan dengan objek suatu wacana. Cara bercerita itu terbentuk dalam sebuah kemasan. Kemasan itu semacam skema yang disampaikan, serta untuk menafsirkan makna-makna pesan yang ia terima (Eriyanto, 2002: 67).

Menurut G.J Aditjondro, framing adalah metode penyajian realitas dimana kebenaran tentang suatu kejadian tidak diingkari secara total, melainkan dibelokan secara halus, dengan memberikan sorotan terhadap aspek-aspek tertentu saja, dengan menggunakan istilah-istilah yang meliki konotasi tertentu, dan dengan bantuan foto, karikatur, dan alat ilustrasi lainnya. sedangkan menurut Aditjondro (Siahaan 2001: 9-10) menjelaskan bahwa proses framing merupakan bagian tak terpisahkan dari proses penyuntingan yang melibatkansemua pekerja di bagian ke redaksian media. Reporter dilapangan menentukan siapa yang diwawancarainya. Redaktur, dengan atau tanpa konsultasi dengan redaktur pelaksanaan, menentukan apakah laporan si reporter akan dimuat atau tidak dan menetukan judul apa yang akan diberikan.

Analisis framing dalam penelitian biasanya dipakai untuk membedah cara-cara atau ideologi media saat mengkonstruksi fakta. Analisis framing juga mencermati cara-cara media melakukan seleksi penonjolan fakta kedalam berita agar lebih bermakna, lebih berarti atau lebih diingat, untuk dapat menggiring interpretasi khalayak sesuai dengan perspektif media. Berarti dapat disimpulkan, framing adalah pendekatan untuk mengetahui bagaimana perspektif atau cara pandang yang digunakan oleh wartawan ketika menyeleksi isu dan menulis berita. Cara pandang atau perspektif itu pada akhirnya menentukan fakta apa yang diambil, lalu bagian mana yang ingin ditonjolkan maupun dihilangkan, serta akan dibawa kemana berita tersebut (Fauzi, 2007: 23).

$$
\text { Pan \& Kosicki (1993: 56-57) }
$$
menyatakan, framing dapat dipelajari sebagai 
suatu strategi untuk memproses dan mengkonstruksi wacana berita atau sebagai karakteristik wacana itu sendiri. Proses framing berkaitan erat dengan rutinitas dan konvensi profesinal jurnalistik. Proses framing tidak dapat dipisahkan dari strategi pengelolahan dan penyajian informasi dalam presentasi media. Framing merupakan bagian integral dari proses redaksional media massa. Dominasi suatu frame dalam wacana berita bagaimanapun berkaitan dengan proses produksi berita yang melibatkan unsur-unsur seperti reporter, redaktur, dan lain-lain.

\subsection{Kontruktivisme}

Konstruktivisme memandang bahwa, media massa mengkonstruksi informasi dan mendistribusikannya kepada masyarakat. Media dipandang tidak mungkin melakukan peranan yang netral, terisolasi dari berbagai pengaruh terhadap dirinya baik yang bersumber dari internal organisasi media maupun dari luar media. Dalam kontruktivisme masyarakat juga bukan hanya sekedar menerima informasi yang diterima tetapi masyarakat dapat mengkonstruksinya berdasarkan pemikiran masing-masing.

Dan menurut Stuart Hall (Sudibyo, 2001: 55), media dipandang sebagai instrumen ideologi melalui mana kelompok menyebarkan pengaruhnya dan dominasinya kepada kelompok lain. Media bukan ranah yang netral yang mengakomodir berbagai kepentingan dan pemaknaan dari berbagai kelompok mendapat perlakuan yang sama seimbang. Peranan media adalah untuk mendefinisikan realita dan ideologi dominanlah yang biasa lebih berperan dalam hal ini.

Adapun tahapan pembentukan konstruksi: ${ }^{1}$

\section{a. Tahap Pembentukan Konstruksi Realitas}

Tahap berikut setelah sebaran konstruksi, dimana pemberitaan telah sampai pada pembaca dan pemirsa, yaitu terjadi pembentukan konstruksi realitas masyarakat melalui tiga tahapan yang berlangsung. Pertama, konstruksi realitas pembenaran sebagai suatu bentuk konstruksi media massa yang terbentuk di masyarakat yang cenderung membenarkan apa saja yang ada di media massa sebagai suatu realitas kebenaran.

Kedua, kesediaan di konstruksi oleh media, yaitu sikap generik dari tahap pertama. Bahwa pilihan orang untuk menjadi pembaca dan pemirsa media massa adalah karena pilihannya untuk bersedia pikiran-pikirannya di konstruksi oleh media massa. Ketiga, menjadi konsumsi media massa sebagai pilihan konsumtif, dimana seseorang secara habit tergantung pada media massa.

\section{b. Tahap Pembentukan Konstruksi Citra}

Konstruksi citra bisa berupa bagaimana konstruksi citra pada sebuah pemberitaan atau bagaimana konstruksi citra pada sebuah iklan. Konstruksi citra pada sebuah pemberitaan biasa di siapkan oleh orang-orang yang bertugas didalam redaksi media massa, mulai dari wartawan, editor, dan

\footnotetext{
${ }^{1}$ Santono, Puji.Konstruksi Sosial Media Massa. Universitas Muhamadiyah Sumatera Utara. http://www.Jurnal.uinsu.ac.id. Diakses pada 19/10/19 Pukul 15.00 WIB
} 
pimpinan redaksi. Sedangkan konstruksi citra pada sebuah iklan biasanya disiapkan oleh para pembuat iklan, misalnya copywriter.

\section{c. Tahap Konfirmasi}

Konfirmasi merupakan tahapan ketika media massa maupun pembaca dan pemirsa memberikan argumentasi dan akuntabilitas terhadap pilihannya untuk terlibat dalam tahapan pembentukan konstruksi. Bagi media, tahapan konfirmasi ini perlu sebagai bagian untuk memberi argumentasi terhadap alasanalasannya konstruksi sosial. Sedangkan bagi pemirsa dan pembaca, tahapan ini juga sebagai bagian untuk menjelaskann mengapa ia terlibat dan bersedia hadir dalam proses kontruksi sosial.

\subsection{Identifikasi Frame}

Tujuan media adalah terartikulasinya makna yang disampaikan melalui bahasa yang digunakan. Disinilah kita harus mencurigai dan mengantisipasi bahwa berita yang diterima mengandung muatan ideologis. Menurut Gunther Kress menjelaskan bahwa kata sistem yang di organisasikan oleh, dan merepresentalisasikan sistem ideologi. Dengan demikian, kata seperti "pejuang kebebasan" atau teroris tidak lahir di ruang hampa (Kress, 1984: 130).

Dalam meneliti atau menganalisa surat kabar, elemen framing diatas menjadi unit perhatian peneliti atau analis. Pada intinya, frame, harus ememnuhi empat kriteria :Pertama, frame berita harus memiliki karakteristik konseptual dan linguistik yang dapat di identifikasi. Kedua, secara umum harus bisa di amati dalam kegiatan jurnalistik.
Ketiga, harus mampu membedakan secara tepat antara frame disuatu media dengan frame di media lain. Keempat, Frame harus memiliki validitas representasional (diakui oleh orang lain) dan tidak sekedar lintasan khalayak peneliti saja.

\section{Metode Penelitian}

Penelitian ini bersifat kualitatif deskripsi, yaitu berusaha menggambarkan dan menjelaskan framing Radar Cirebon pada peristiwa penangkapan teroris JAD oleh Densus 88 di Kota Cirebon. Paradigma yang digunakan dalam penelitian ini adalah paradigma konstruktivisme. Paradigma ini dipilih karena terkait dengan metode analisis data yang digunakan framing.

Kemunculan berbagai peristiwa dalam berita merupakan hasil rekonstruksi dan interpretasi yang dilakukan oleh media, maka untuk melihat frame Radar Cirebon terhadap berita Penangkapan Teroris JAD oleh Densus 88 di Kota Cirebon, peneliti menggunakan analisis Framing model Zhongdan Pan \& Gelard M. Kosicki, yang dirumuskan dalam struktur sintaksis, struktur skrip, struktur tematik dan struktur retoris. Ada empat dimensi struktur yang dianalisa pada pendekatan analisis framing model Pan \& Kosicki. Kemepat dimensi itu sebagai berkut:

Struktur sintaksis yaitu bagaimana wartawan menyusun fakta atau peristiwa yang berupa pernyataan opini, kutipan, pengamatan atas peristiwa dalam bentuk susunan umum berita. Perangkat framing adalah skema berita dan unit yang diamati adalah headline, lead, latar informasi, kutipan, sumber, pernyataan 
dan penutup. Struktur sintaksis dapat memberikan petunjuk yang berguna tentang bagaimana wartawan memaknai peristiwa dan hendak kemana berita itu akan diarahkan.

Struktur skrip, yakni bagaimana wartawan mengisahkan fakta. Struktur ini melihat bagaimana strategi cara bercerita atau bertutur yang dipakai oleh wartawan dalam mengemas peristiwa dalam bentuk berita. Perangkat framingnya adalah kelengkapan berita dan unit yang diamati adalah $5 \mathrm{~W}+1 \mathrm{H}$.

Struktur tematik, yakni bagaimana wartawan menulis fakta atau bagaimana wartawan menungakan pandangannya terhadap suatu peristiwa ke dalam proposisi, kalimat atau hubungan antarkalimat yang membentuk teks secara keseluruhan. Perangkat framing dari struktur tematik ini terdiri dari detail, maksud, nominalisasi, koherensi bentuk kalimat dan kata ganti.
Sedangkan unit yang diamati adalah paragraph, proposisi, kalimat dan penghubung antarkalimat. Struktur tematik digunakan untuk melihat bagaimana fakta itu ditulis, bagaimana kalimat dipakai, bagaimana menempatkan dan menulis sumber ke dalam sebuah teks berita secara keseluruhan

Struktur retoris yakni bagaimana wartawan menekankan fakta. Perangkat framing yang digunakan adalah leksion, grafis, pengandaian dengan unit analisa kata, idiom, gambar foto dan grafik. Unsur leksikon menunjukan pilihan kata dalam suatu kalimat tertentu. Pemuatan gambar, foto, angel, grafik, warna. Selain itu penggunaan gaya bahasa fantastis dan methapor atau kata kiasan juga akan memperlihatkan penekanan yang dilakukan oleh wartawan. Berikut adalah tabel model analisis framing yang dikembangkan Pan dan Kosicki:

Tabel 1. Kerangka Framing Pan dan Kosicki

\begin{tabular}{ccc}
\hline STRUKTUR & PERANGKAT FRAMING & UNIT YANG DIAMATI \\
\hline $\begin{array}{c}\text { SINTAKSIS, cara } \\
\text { wartawan menyusun fakta }\end{array}$ & Skema berita & $\begin{array}{c}\text { Headline, lead, latar } \\
\text { informasi, sumber kutipan, } \\
\text { pernyataan, penutup. }\end{array}$ \\
\hline $\begin{array}{c}\text { SKRIP, cara wartawan } \\
\text { mengisahkan fakta }\end{array}$ & Kelengkapan berita & $5 \mathrm{~W}+1 \mathrm{H}$ \\
\hline $\begin{array}{c}\text { TEMATIK, cara wartawan } \\
\text { menulis fakta }\end{array}$ & Detail, detil, koheren, bentuk, \\
kalimat, kata ganti & $\begin{array}{c}\text { Paragraft, proposisi, kalimat, } \\
\text { hubungan antarkalimat }\end{array}$ \\
\hline $\begin{array}{c}\text { RETORIS, cara wartawan } \\
\text { menekankan fakta }\end{array}$ & Leksikon, grafis, metafor & Kata, idiom, gambar/foto, \\
grafik
\end{tabular}




\section{Hasil dan Pembahasan}

Pada rentang waktu tanggal 14 October 2019 sampai 19 October 2019 dapat dipaparkan berikut ini: pada 14 October 2019 Radarcirebon.com menurunkan berita yang berjudul "Kronologi Penangkapan Terduga Teroris Cirebon”, tanggal 17 October 2019 membuat berita berjudul "40 Terduga Teroris Ditangkap Densus 88 Jelang Pelantikan Presiden", pada tangga 18 October 2019 pukul 08.00 WIB, memuat berita berjudul "Dua Rumah Terduga Teroris JAD di Geledah Densus 88 dan Polres Ciko". Pada hari yang sama, disusul penurunan berita yang berjudul "Di Wilayah Hukum Polres Ciko, Empat Terduga Teroris JAD di Tangkap Densus 88”. Pada penelitian ini, peneliti akan menjadikan dua judul berita sebagai pembahasan utama, berita tersebut adalah berita pada 18/10/19 “ $D i$ Wilayah Hukum Polres Ciko, Empat Terduga Teroris JAD di Tangkap Densus 88”. Dan pada tanggal 19/10/19, Radar menurunkan berita yang berjudul "40 Terduga Teroris Ditangkap Densus 88 Jelang Pelantikan Presiden".

Dalam kedua judul yang ingin diteliti, berikut hasil analisis terhadap pemberitaan di Radarcirebon.Com :

\section{Berita Berjudul "Di Wilayah Hukum} Polres Ciko, Empat Terduga Teroris JAD di Tangkap Densus 88” (18 October 2019)

Pada tanggal 18 October 2019, Radarcirebon.Com menurunkan berita berjudul "Di Wilayah Hukum Polres Ciko, Empat Terduga Teroris JAD di Tangkap Densus 88". Pertama, dianalisis dari strutur sintaktisnya, wartawan menonjolkan pada tempat teroris dibawa oleh Densus 88, yaitu di Wilayah Hukum Polres Cirebon Kota.

Pada teras beritanya, Radar mengutip narasumber untuk mendukung data yang dijadikan sebagai judul berita tersebut, berikut adalah kutipan teras berita Radarcirebon.Com:

Selama sepekan ini Tim Densus 88 gencar menangkap sejumlah orang yang diduga teroris Jaringan Jamaah Ansharut Daulah (JAD) Cirebon di Wilayah hukum Polres Cirebon Kota. Bahkan, sejumlah rumah di Wilayah Hukum Polres Cirebon Kota pun tak luput digeledah Tim anti teror ini.

Dari elemen Skrip, Radar memberikan ruang lebih besar untuk menyampaikan respos Kepolisian Kota Cirebon atas penangkapan 4 teroris JAD tersebut. diungkapkan data jumlah teroris yang sudah ditangkap oleh Densus 88 di Wilayah Hukum Polres Cirebon Kota berjumlah 4 orang. Hal ini bisa dilihat dalam kutipan diberita dibawah ini:

Kapolres Cirebon Kota AKBP Roland Ronaldy, mengatakan "kalau jumlahnya terduga teroris yang ditangkap Densus 88 bersama kami (Polres Ciko, red) di wilayah hukum Polres Ciko itu ada empat orang. Dan semua nya masih jaringan JAD, mereka adalah B,S,A dan W". Kata Roland.

Dari sisi Retoris, Radar menekankan berita pada gambar/foto yang ada pada headline dan ditengah berita. Pada headline berita ini wartawan menampilkan foto Anggota Densus 88 yang ingin menagkap terduga teroris $\mathrm{JAD}$, dalam foto tersebut terlihat ada 5 anggota Densus 88 yang membawa senjata. Foto kedua, terlihat kumpulan barang bukti dan sejumlah senjata 
tajam. Dalam foto tersebut wartawan menambahkan caption "kata AKBP Roland Ronaldy, selama penggeledahan di rumah para terduga ditemukan sejumlah senjata tajam, buku-buku dan benda yang dianggap berbahaya lainnya".

Tabel 2.

Judul Berita : Di Wilayah Hukum Polres Ciko, Empat Terduga Teroris JAD di Tangkap Densus 88

Tanggal : 18 October 2019

Framing $\quad$ : Penangkapan 4 Teroris dan Penemuan Barang Bukti

ELEMEN

\section{FRAMING PENULISAN}

\begin{tabular}{cl}
\hline SKEMATIS & $\begin{array}{l}\text { Wartawan lebih menonjolkan judul headline dari sumber kutipan berita yang } \\
\text { didapat dari Kepolisian Kota Cirebon }\end{array}$ \\
\hline SKRIP & $\begin{array}{l}\text { Radar memberikan ruang lebih besar untuk menyampaikan respos Kepolisian } \\
\text { Kota Cirebon atas penangkapan } 4 \text { teroris JAD }\end{array}$ \\
\hline TEMATIK & $\begin{array}{l}\text { Sebanyak empat orang terduga teroris jaringan JAD ditangkap Densus 88 di } \\
\text { Wilayah Hukum Polres Cirebon Kota }\end{array}$ \\
\hline RETORIS & $\begin{array}{l}\text { Radar menekankan berita pada foto/gambar pada headline dan ditengah berita. } \\
\text { Wartawan menampilkan foto Densus } 88 \text { beserta Teroris yang tertangkap dan } \\
\text { foto barang-barang bukti milik teroris JAD }\end{array}$ \\
\hline
\end{tabular}

2. Berita berjudul "40 Terduga Teroris Ditangkap Densus 88 Jelang Pelantikan Presiden" (19 October 2019)

Tanggal 19 October 2019 Radarcirebon.Com menulis berita yang berjudul "Dua Rumah Terduga Teroris JAD di Geledah Densus 88 dan Polres Ciko”. Dilihat dari struktur sintaksisnya, melalui perangkat framing berupa skematis, berita Radar Cirebon.Com lebih mengedepankan sumber dari pihak kepolisian kota Cirebon. Hal ini dapat terlihat dari judul berita yang menyatakan bahwa 40 terduga teroris ditangkap densus 88, data 40 terduga yang diperoleh dari data Kepolisian Kota Cirebon wartawan gunakan untuk membuat headline judul berita. Artinya, dalam isu ini, Radar Cirebon lebih berpihak pada sumber versi kepolisian dan menjadikan data tersebut sebagai judul headline berita. Pernyataan dari data kepolisian yang dijadikan judul berita dikutip dari narasumber Kepolisian. Berikut kutipannya:

"jadi, kemarin ada 36 terduga teroris ditangkap. Dan pada hari ini (kemarin) bertambah 4 orang jadi total 40 terduga teroris yang ditangkap hingga hari ini. kemepat terduga teroris tambahan yang ditangkap yakni OA, W, A dan A alias aulia," Kata Karopenmas Human Polri Brigjen Pol Dedi Prasetyo.

Pada teras beritanya Radar mengutip narasumber dari Kepolisian, yang menyatakan 
bahwa seluruh terduga teroris berkaitan dengan kelompok Abu Zee JAD. Berikut kutipannya:

Kabid Humas Polda Metro Jaya Kombes Pol Argo Yuwono mengatakan Adnan Aulia alias Gondrong diduga terkoneksi dengan penangkapan empat terduga teroris Lampung "seperti yang dikatakan Mabes Polri, seluruh terduga teroris punya keterkaitan dengan kelompok Abu Zee pimpinan JAD Bekasi dan perekrut Abu Rara pelaku penyerangan ke Pak Wiranto, termasuk empat yang dari lampung".

Dari elemen skripnya, Radar memberikan ruang yang lebih besar untuk menyampaikan respon atau langkah kepolisian atas kejadian itu secara lengkap dan terperinci, seperti menjelaskan data dari Kepolisian tentang keterlibatan Adnan dalam kelompok media sosial pendukung ISIS atau Daulah hingga pengungkapan perakitan bom aksi bunuh diri yang dilakukan oleh Adnan.

Dari sisi Retoris, Radarcirebon.com, untuk menekankan fakta wartawan menonjolkan dari segi data dari Kepolisian dengan disajikan nya jumlah teroris yang tertangkap oleh Densus 88 dan juga profil dari 4 teroris yang baru ditangkap. Berita juga ditekankan pada gambar yang disajikan oleh wartawan, dengan gambar 2 anggota Densus 88 menangkap 3 orang teroris dengan menggunakan baju tahanan dan penutup wajah. Berikut tampilan temuan penelitian yang akan disajikan dalam tabel dibawah ini:

\section{Tabel 3.}

Judul Berita : 40 Terduga Teroris Ditangkap Densus 88 Jelang Pelantikan Presiden

Tanggal : 19 October 2019

Framing $\quad: 40$ Terduga Teroris JAD Ditangkap

\section{ELEMEN FRAMING PENULISAN}

SKEMATIS Radarcirebon.Com dalam penulisan beritanya lebih mengedepankan sumber pihak Kepolisian, Kabid Humas Polda Metro Jaya Kombes Pol Argo Yuwono untuk memframing berita penangkapan 40 Teroris oleh Densus 88 .

SKRIP Langkah-langkah kepolisian atas kejadian itu dituangkan secara lengkap dan terperinci. Disampaikan (jumlah awal dan terbaru teroris yang tertangkap serta beberapa latar belakang identitas teroris JAD Cirebon).

TEMATIK Seluruh terduga teroris punya keterkaitan dengan kelompok Abu Zee pimpinan JAD Bekasi dan perekrut Abu Rara pelaku penyerangan ke Pak Wiranto.

RETORIS Menonjolkan penekanan pada data Kepolisian sebagai sumber berita dan memberikan foto berita pada headline foto 2 anggota Densus 88 menangkap 3 orang teroris dengan menggunakan baju tahanan dan penutup wajah. 


\section{Daftar Pustaka}

Eriyanto. 2002. Analisis Framing Konstruksi, Ideologi dan Politik Media. Yogyakarta: LkiS

Fauzan, Hary. 2019. "40 Terduga Teroris Ditangkap Densus 88 Jelang Pelantikan Presiden".

http://www.RadarCirebon.Com. Diakses pada 20/10/19 pukul 15.20 WIB

Fauzi, Arifatul Choiri. 2007. Kabr-Kabar Kekerasan Dari Bali. Yogyakarta: LkiS

Karman. 2012. Media dan Konstruksi Realitas Analisis Framing Pemberitaan Koran Tempo Mengenai Kasus Peledakan Bom di Masjid Malpors Cirebon. http://www.jurnalstudikomunikasi.com. Vol. 16. No 1 (Januari-Juni 2012).

Diunduh pada 19/10/19 pukul 17.50 WIB

Kress, Gunther. 1984. "Transformasi Linguistik dan Ideologis dalam Peliputan Berita", dalam Bahasa, Citra, Media, ed. Howard Davis, and Paul Walton, 125146. Yogyakarta: Jalasutra

Littlejohn. W. Stephen. 1996. Theories of Human Coomunication. Fifth edition. Belmont: Wadsworth

Rdh. 2019. "Di Wilayah Hukum Polres Ciko, Empat Terduga Teroris JAD Ditangkap Densus 88". http://www.radarcirebon.com. Diakses pada 19/10/19 pukul 20.16 WIB

Santono, Puji.Konstruksi Sosial Media Massa. Universitas Muhamadiyah Sumatera Utara. Jurnal, http://www.Jurnal.uinsu.ac.id. Diakses pada 19/10/19 Pukul 15.10 WIB

Siahan, Hotman. 2001. Pers Yang Gamang: Studi Pemberitaan Jajak Pendapat Timor-Timur. Jakarta: Institute Studi Arus Informasi

Sudibyo, Agus. 2001. Politik Mediadan Pertarungan Wacana. Yogyakarta: LKiS 